\title{
Islamic Political Development and New Media: A case Review in Malaysia from 2002 to 2012
}

Aminaton Hajariah Husnu, Russli Kamarudin

To Link this Article: http://dx.doi.org/10.6007/IJARBSS/v11-i3/9278

DOI:10.6007/IJARBSS/v11-i3/9278

Received: 14 January 2021, Revised: 17 February 2021, Accepted: 02 March 2021

Published Online: 29 March 2021

In-Text Citation: (Husnu \& Kamarudin, 2021)

To Cite this Article: Husnu, A. H., \& Kamarudin, R. (2021). Islamic Political Development and New Media: A case Review in Malaysia from 2002 to 2012. International Journal of Academic Research in Business and Social Sciences, 11(3), 1468-1483.

\section{Copyright: @ 2021 The Author(s)}

Published by Human Resource Management Academic Research Society (www.hrmars.com)

This article is published under the Creative Commons Attribution (CC BY 4.0) license. Anyone may reproduce, distribute, translate and create derivative works of this article (for both commercial and non-commercial purposes), subject to full attribution to the original publication and authors. The full terms of this license may be seen at: http://creativecommons.org/licences/by/4.0/legalcode

\section{Vol. 11, No. 3, 2021, Pg. 1468 - 1483}

Full Terms \& Conditions of access and use can be found at http://hrmars.com/index.php/pages/detail/publication-ethics 


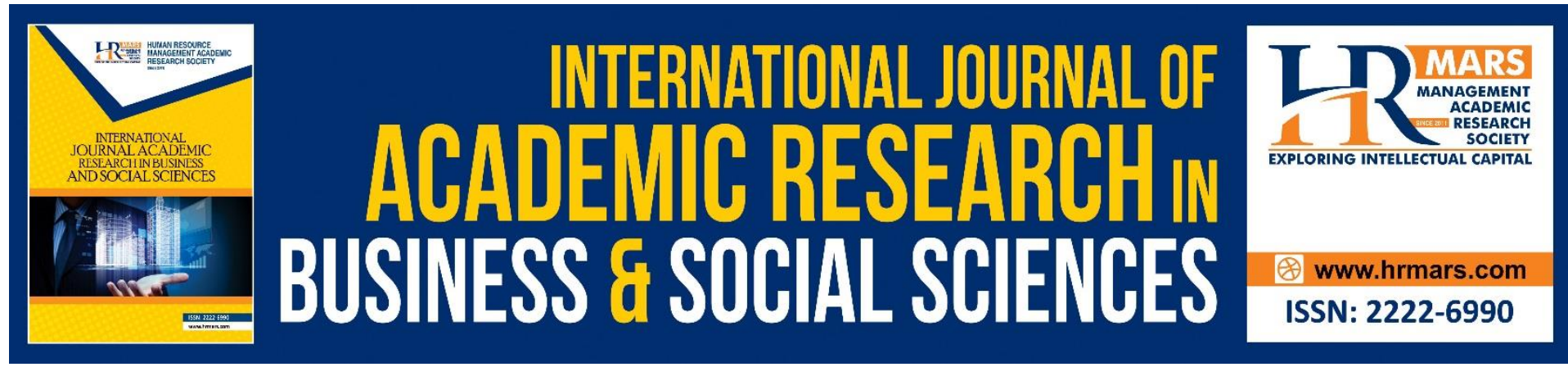

\title{
Islamic Political Development and New Media: A case Review in Malaysia from 2002 to 2012
}

\author{
Aminaton Hajariah Husnu, Russli Kamarudin \\ Faculty of Social Sciences and Humanities, The National University of Malaysia
}

\begin{abstract}
This study is to identify the use of new media for political campaigns particularly for Islamic political campaigns. Results of this study have found that the new media is very important medium used by politicians in their campaigns to influence the society. The researchers have listed several websites associated with Islamic politics in Malaysia. This study is also aimed to discuss issues related to Islamic politics in Malaysia as commonly discussed in blogs, websites, face book and other internet applications. This study adopted a combination of qualitative and quantitative methods. Qualitative method involves literature reviews and contents analysis survey to resolve several questions with regards to various new media previously utilized in the development of Islamic politics. In addition, this study also examines the role played by the new media in influencing the society's attitudes towards Islamic politics. Quantitative method was used through a survey which was conducted using questionnaire to determine how new media was used as the channel to discuss Islamic politics and to determine the role played by the new media in the development of Islamic politics today. 627 respondents were randomly selected in Malaysia based on gender, races, age and residential areas. Data was analyzed using the SPSS version 10.0 involving descriptive analysis to find frequency and percentage. Results of the study have found that $83.3 \%$ respondents agreed that the development of Islamic politics was influenced by the new media. Whereas, $99.4 \%$ respondents experienced current technology development (new media) like face book account, twitter, and blogs. $98.7 \%$ respondents agreed that most politicians have used the new media as one of their campaigning methods to attract voters and $85 \%$ of respondents agreed that the new media helps the society to increase their knowledge on Islamic politics. The implication of the study is the development of Islamic politics in Malaysia is greatly influenced by the emergence of new media, hence it has significant impact on political development in Malaysia.
\end{abstract}

Keywords: Islamic, Politics, New, Media, Influence, Review.

\section{Introduction}

Media technology plays a very important role in our daily life. It is also commonly associated with political scenario in Malaysia. The more we exploit information in the media, the more knowledge we can get in whatever areas namely social, business, fashion, and politics. ${ }^{1}$ There is unlimited information to be easily gained from the media. Due to rapid development of

1 Anwar, 1995, page 10. 
technology in Malaysia, there are also various issues published by the media. At present, Islamic politics is the talk of the town and media can easily and quickly disseminate various information and details of certain issues. Indirectly, discussions on issues associated with Islamic politics are spreading with the help of additional information published by the blog ${ }^{2}$, face book ${ }^{3}$, website, twitter ${ }^{4}$ owners.

Malaysia is experiencing a rapid development in many areas, but the use of blog application to share ideas, to voice out opinion and personal views is still very new and rare. However, there are several factors which encourage the development of blogs as alternative media in Malaysia. The main factor is due to the restriction imposed on the mainstream media. Most mainstream media is under the influenced of political stakeholders, which control the contents of the information to be published and released (Hussain, 1998). In this globalization era, other that religion, people are obsessed with the new spirit called transformation. Internet is the new ' it", hence, people are obsessed and possessed by all kind of information in it. In fact, people are easily agreed and influenced by its power to shape and determine the future.

The person who controls the new media, he indirectly has acquired a future influence. The new media has greatly influenced today's political situation in Malaysia. In fact, the growth of Islamic political was also influenced by new media (Koike \& Makato, 2002). There are three phases of Internet wave: the first phase is the web, the second phase introduced blog applications particularly the blogspot, and word press. The third phase brought social sites like twitter, face book, my space, and so on. At present, Malaysia is undergoing the third phase of the Internet wave. Although Malaysia is still experiencing the third wave, but the use of web and blogs are popular among politicians and the public. This is because all three phases are interconnected and very important in the dissemination of information especially it is the best source of latest information either in the economic, social or even political in particular.

\section{The Concept of Islamic Politics}

In understanding the concept of Islamic politics, the authors describe in detail the meaning of politics. Politics means managing affairs related to the community, internal as well as external affairs. In other words, politics is sustaining all aspects of community's life. Therefore, politics can be described in various ways and involves a variety of things, in can be maintaining public affairs in terms of education and learning community through the development and direction of educational and learning policies. Secondly, politics involves managing community affairs in the field of information, such as by making constructive information policy, by trying to improve and enhance mankind in the aspects of thoughts, souls, and attitudes. Thirdly, politics involves the actions taken to maintain people's affairs economically and life's necessities (Sobari 2010). In overall, politics can be characterized as a comprehensive life aspect namely, education, learning, judiciary, executive, economy, military, knowledge, monetary, cultural, arts and many more. In addition, in involve a comprehensive aspect of

\footnotetext{
2 John Barger (1997) blog is the short form of weblog. This term is used by him in December 1997. John Barger has been using the weblog term to refer to a bunch of personal updated websites which are links with the other interesting website with personalised commenting sections .

In conclusion, weblog is personal space to upload images, writing ideas, experience and public issues.

${ }^{3}$ Facebook is a social link to connect an individual with others regardless of time and place but a Facebook account. It was created by Mark Zuckerberg, and his friends Eduardo Saverin, Andrew McCollum, Dustin Moskovitz and Chris Hughes on 4 February 2004.

${ }^{4}$ Kelly, Ryan, ed. (2009) said that twitter is a social networking and micro-blogging which allow users to send and read messages called tweet, it is a short text of at least 140 characters shown on the owner's profile page and then can be sent to the "followers". It was first established in 2006. By Jack Dorsey, Chairman Evan Williams, CEO Biz Stone, Creative Director.
} 
internal and external life. In relevant to that, religion is not isolated from politics and vice versa, politics cannot be separated from religion. In fact, politics should be pillared from religion.

There are shallow opinions and views which isolated politics from religion. This perception is dangerous to the values and ethics of administration, in fact, people who uphold this belief would cause politics to be too shallow, empty, and worthless. In addition, politics would only serve for the benefits of the political parties, individuals of groups (Sumarsono, 2001). Apart from that, this kind of politicians would create 'Machiavellian's political environment, which refers to an environment fulls of unscrupulous people who administer others with manipulation, and insincerity. People would resort to anything in order to achieve their own personal agenda. Hence, it is unacceptable by the Islamic perspective. In Islam, everything be it religion or a mighty country, all are actually nothing in the eyes of Allah, in fact every single thing belongs to Him $\left(\right.$ kaisar $\left.^{6}\right)$. Hence, there is no separation between religion and a country or between politics and religion. Religious politics should be established based on religious values, norms and attitudes.

The word politics is reflecting administration and management policies. In the context of a country, it is an administration strategy and management technique to be used in administrating the whole country. Again, the term politics rooted from Islam as Muslim people are expected to have a strong belief on their mighty God and they are required to obey the Islamic rules. Hence, religion is an influential foundation particularly in managing economy, political and social aspects (Thaib 1998). Abdullah (2003) defined politics from the Islamic perspective as administrative or knowledge of social behavior. The term and concept of politics are defined differently by the non-Muslims. However, politics in Islam covers every aspect of people's life, and it should be practiced and ruled based on an Islamic system and the religious' rules.

According to Al-Maududi (1986), the concept of Islamic politics puts Allah (the God) as the first and the mightiest not people. This concept is of course different from the concept of democracy, which puts certain people as its sovergnity especially on law and regulation for other citizens to obey. He also criticized democracy due to its failure in curbing and controlling problems especially related to social, economy and politics. He added that, people's slogans are worthless and too rhetoric as they denied the authority of Allah simply by putting mere mortals who have flows and weaknesses ${ }^{7}$ as their superiors. Politics can also be classically defined as the ability to administer and organize something perfectly and orderly. Politics can also be defined as judiciary or laws, specially formulated to maintain many aspects of life including attitudes, behaviors, welfare and peacefulness (Awang,2009). According to Sobari from al-Hanafi (2010), Islamic politics involves actions taken by the leaders in order to achieve his goals and objectives. Whereas another Muslim scholar described politics as something that brings people closer to goodness and away from evils,

\footnotetext{
5 Sumarsono, 2016, hlm 56. Machiavelli is one of the philosophers in the renaissance era. He was born in 1946 at Florence, Italy. He is famous in political discipline and was seen as a political philosopher. He wrote a book entitled 'The Prince'. The book is very important for rulers and leaders of a country in order to achieve succes. Machiavellian politics allows any method used to achieve something. To maintain his position, the ruler should do anything or even resorts to any mean of conduct

${ }^{6}$ Witzel M. 2001. Autochthonous Aryans? The Evidence from Old Indian and Iranian Texts. Elect. J. Vedic Studies 73:1-93. p.29.

${ }^{7}$ Nasr, Seyyed Vali Reza, 1996, Mawdudi \& The Making of Islamic Revivalism. Oxford University Press.
} 
even though that something is never been done by the Prophet. Based on all the above definitions, the authors can conclude that there are two types of Islamic politics.

The first type is related to the law of various things and events which are not mentioned in the Holy Quran, Sunnah or ijmak, and never been discussed by any group of Islamic scholars. The second type of Islamic politics is more contemporary and flexible in nature. The law and rules are changed depending on situations and condition of the society. In other words, it involves events or occurrences which are not stated in any religious statements and Holy Quran. Whatever it is, Islamic politics is the best way to ensure a fair implementation of laws and verdicts by adhering the religious laws as stated in the Holy Quran and practiced by the Prophet and Islamic scholars.

In conclusion, it is important for leaders to administer their government based on the Islamic rules and laws, instead of formulating their own governing strategies. In the concept of Islamic politics, whenever Islamic law is implemented, it is compulsory for the people or the citizens to oblige and to obey. This is because the leader is the $B a^{\prime} i a h^{8}$ of his people, or he is appointed by his people to rule the country based on the Islamic rules. Hence, it is the responsibility of the leader to play his role accordingly and at the same time to fulfill the needs of his people. Due to that, the people have the right to dispel and strip down any leader who fails in fulfilling his duty. Hence, this initially created the need to have opposition leaders or parties in politics. In conclusion, the concepts of Islamic politics are clearly stated and taught that Allah is the highest and the mightiest power, and it is the responsibility of the ruler or leader to administer the state according to the rules stated in the holy statements.

\section{Political Concept and New Media}

Politics in Malaysia is interrelated with the new media. The current Malaysian political scenario is moving toward internet practical understanding when compared to the $12^{\text {th }}$ general election five years ago. The $13^{\text {th }}$ general election showed a new phenomenon as the parties, leaders and supporters were preparing ahead and in advance of the Election Day. Blogs, websites, face book, twitter, and other social media for the public to access and judge published various information. Supporters of Pakatan Rakyat (PR) were dominant in the use of new media to influence people's thinking, however, Barisan Nasional especially members of The United Malays National organization (UMNO) have improved in the use of the new media as one of their platforms for campaigns (Hussain et. Al, 2005).

Aristotle's had said that as long as people are social animals, hence there would always be politics. Apart from that, he viewed politics and people as interconnected entities. People have a special connection and the connection has its own circle of life. There is power and influence held by every individual, groups of people to be followed by others, or rules. However, it depends on the people or citizens to follow or ignore the rules, as well as to determine the rewards or punishment for those who obey and disobey the rules. From etymology point of view, politics derived from the Greek language meaning "city". People of the city are called 'polities' or citizens. Whereas the word 'politikus' means citizenship. Later a new word was coined, 'politike techne' which means political skills. Another related term is

${ }^{8} \mathrm{Ba}$ 'iah is a formal agreement or a risk-based agreement. Ba'iah has official holy statements in the history and Islamic knowledge. The Holy Quran and Hadith have clearly described the concept of ba'iah. Particularly with regards to the Aqabah and Hudaibiyah Agreements (Ghazali Darusalam 1998). 
'Ars politica' which was defined as skills related to nation state and the latest word is 'politike epitesme' which means political knowledge (Martinez \& Patricia, A. 2001).

The word politics can be defined in many ways and it depends on one's point of view toward politics as a whole. According to Budiardjo (1993), politics is everything that happens in a country as a process to achieve an objective, a goal and a target, and the ways to achieve it. Whereas, Hoogerwerf (1999) defined politics as efforts taken to achieve success and also a power struggle. According to David Easton (1997), politics involves all activities that are powerfully influence others' intelligence and then the intelligence is then used or manipulated by the leaders. Politics is significantly interconnected with power. Power is one's ability to influence other is attitudes and behaviors to agree with his opinion or point of view. According to Lasswel and Kaplan (1950), political knowledge is learning about developing and dividing power. Whereas, according to Robson (2009), politics is a learning discipline about power in a society, it involves the efforts to know about policies, process, nature, areas and the outcomes. The main concerns of politics are on the struggles to achieve its objectives, and to retain the power, to influence others, to execute power as well as to oppose the implementation of power.

New media is referred to interactive media between people and the computer particularly the internet ${ }^{9}$. The features of the new media are websites, blogs, online social links, online forum, and other computer-based interactive applications. Radio and television are other types of media but they are categorized as the "old" media. The use of new media has been intensified and utilized to deliver messages creatively and innovatively (Halizah, 2012). The new media is also famously known as the digital theory, which allows people to interact with technology. Digital theory is a new concept of understanding the evolution of science and technology, from manual to automotive and from complication to simplification. This digital era is now the main part of everyday's life, it involves complex methods but flexible. Apart from that, the digital theory is interlinked with the media theory, as both are ever changing. Currently, the new media is rapidly developed in the context of information and communication technology. The new media is the main channel to connect people and to link people with technology regardless of places, religions, races and countries. For instance, the most effective new media are the internet, social applications, websites and mobile phones which allow people to access information conveniently (Axford \& Huggins, 2001).

The old media was developed several centuries ago. The media such as radio, television and printed media were the first technology to connect people by channeling various information and latest news. Even though, television is considered an old media, but it is still as effective as the internet. Both, television, and internet are powerful in influencing public reactions and points of views simply by providing certain issues and topics of discussion (Axford \& Huggins, 2001). In today's era of globalization, the new media particularly blogs, websites, face book and twitter are cyberspace social connection, which rapidly becoming the most important media for people to discuss issues and topics. However, some social accounts that belong to public figures are actually handled by their assistants, hence, their social accounts such as twitter and face book are sometimes unreliable. Apart from that, most

${ }^{9}$ Kamus Dewan Edisi ke-4, internet is the acryonym of Interconnected Computer Networks or borderless computer network which links users with other users from different part of the world. 
political leaders do not fully utilized their social networks, the interaction is done as a oneway communication, lack of interaction with the viewers (visitors/followers), ideas are not discussed intelligently and critically (Sulong, 2012).

The party that can effectively influence and control the mind of the young people will have a brighter future in the general election. This is due to the fact that, based on the record of the $13^{\text {th }}$ Malaysian General Election, it was recorded that 48 percent of the voters was those who were at the age of below 40 years old. In fact, a 70 percent voter was young voters who were influenced by the new media. In conclusion, the new media is one of the important factors in future general election. Hence, to ensure a great win, political leaders or the supporters should use the new media, as one of their campaigning strategies, which capable to dominate the minds of at least 30 percent of voters (Sulong, 2012). Therefore, it is safe to say that future political campaigns would experience new phenomena and political leaders need to manage different types of people and should know how to interact with their supporters. Years ago, Barisan Nasional dominated Malaysians through its $3 \mathrm{M}$ concepts of 'money', 'machinery' and 'media', however the concepts are no longer working because the other opposition parties PAS, PKR and DAP are now three strong opponents.

In overall, it can be concluded that, media and politics are two interconnected entities. The new media provides a new platform for politicians and their supporters to expand their party and at the same time trying to influence people's mentality towards certain issues. Any discussion in the media would, like it or not have certain impacts on the position of the political party and its leaders.

\section{Theory of Media Politics}

The best-suited theory for this writing is the theory of media politics. Anthony Downs first proposed this theory. Downs replaced the idea of rational choice approach towards his subjects. Anthony Downs developed this theory in his book entitled 'An Economic Theory of Democracy. This theory was then developed and expanded by Zaller. In 1957, Downs created a political process from the competing parties that competed to get supports from rational voters. Based on the research findings, Downs successfully explained and described various characteristics of politics, which were very important to be applied in the democratic politics in general. However, Downs's theory does not really touch on journalists/reporters. In fact, journalists or reporters were ignored because they did not have freedom in playing their roles in politics (McLuhan \& Marshall, 2011).

Zaller (1999) expanded Anthony Downs's media politics theory. Based on his research, Zaller concluded on the role of journalists in the theory based on Downs's democratic system theory. In overall, Zaller stated that politicians are always trying to find so many ways to communicate with their people, either via cyberspace or via direct face-to-face communication. Apart from that, politicians and supporters are taking efforts to expand their influence in order to get more voters. This is because, without people's vote, a political party and its leader are nothing; of course, the country and the citizens do not need their service. Hence, politicians need to diversify their strategies to influence others for the sake of strengthening their position and continuing their service. This is one of the reasons that new media is expanding and gaining popularity (McLuhan \& Marshall, 2011). Due to that, the media politics theory as proposed by Downs and expansion theory by Zaller are two 
prominent theories, stemmed from politics. Hence, this shows that the Zaller's theory is interrelated with media politics that explains that political news can be published widely and internationally through the new media. For example, political news whether in Malaysia or in America especially its presidential election can be experienced by people of other countries faster with the help of media technology.

Media politics is created because of goal-oriented behavior. This happened because of several factors or several people in the political system including the politics itself, journalists, and the public. Political conflicts commonly happen because of the objectives of the politicians and their influences can gain solid support on direct implication based on the citizens' rational decision (Tehranian \& Majid, 1988). However, it is not easy to influence others' thinking especially on politics, so politicians and their team continuously finding ways to have direct communication with the public and creating itinerary of activities as well as empirical study and theory as proposed by Schattschneider (1942), Schumpeter (1942), Black (1958), and Arrow (1959). Whenever politicians organized a campaign, the media as news covered their activities and their actions. Downs' theory focuses on political parties and assumes that political parties have their own agenda, objectives and goal to be achieved. Some of those are to find opportunities and work spaces to gear their politics towards wider and broader circle of influence. Based on Down's media politics theory, it is found that there is a relationship between the process of influencing others' mind with the ways suggestions and opinions or 'manifesto' 10 are delivered to the society or voters. Knowing that, it is not surprising to see most political leaders are exploiting the new media to influence people's mind.

In the $19^{\text {th }}$ century, the level of communication between political leaders and their voters was at the peak, and it was no longer a major problem for any political candidate to rally supports and to plan strategies of their campaigns. However, the role of old media was still undeniable, as newspapers were still biased towards certain candidates of certain political parties (Fisher, \& Aubrey, 1986).

Now, it is very clear of the new scenario and phenomenons where political leaders are actively communicating with the public via the new media. The new media is free and open in disseminating current topics and issues; of course, it is very powerful to influence others' attitudes. News media is the intermediatory channel between politics and political situations. Whenever reporters interview politicians, the story will be published and the news will be widely read by voters (the society). According to Klepper (1989) in his book 'Advertising Procedure', quoted by Rendra, the word advertising comes from a Greek word meaning influencing the society's mind and the ability to change people's points of view based on statements advertised. This definition is almost similar with Wright's description (quoted by Rendra) about how advertisement is a communication process which has its own strength and it is important as an innovative marketing tool to increase sales, improve service or to give ideas. Thus, current politics is using this opportunity to promote political parties by advertising their political stand through the media. Political advertisement has its own important functions in influencing people's mind. Firstly, political advertisement is capable to persuade and convince people to choose their party. Secondly, it shows different of ideas

${ }^{10}$ Fisher, B. \& Aubrey 1986, stated that manifesto is a program or political plans prepared by parties which taking part in an election and the programs will be executed when they are given the mandate to rule or govern the country. 
and opposite opinions between the candidates. Thirdly, it informs the public about certain vision and mission, as well as various programs that can be mathematically measured. In conclusion, media helps a political party to determine its future. Supports from media or newspapers are very important for politicians to realize their political dreams. In fact, according to Schattschneider (1942), political campaigns through media should be based on one's self-confidence in influencing people's mind and attitudes. Thus, it is confirmed that new media is an important tool for leaders to influence their people.

\section{Results}

Results of the study are based on the answers of the questionnaire. 627 sets were distributed to respondents, which were then analyzed descriptively to answer research questions number three and four. Based on the research finding, it answers the question about how new media can be used as a discussion channel to discuss Islamic politics. Results of the study are shown in the following tables and graphs.

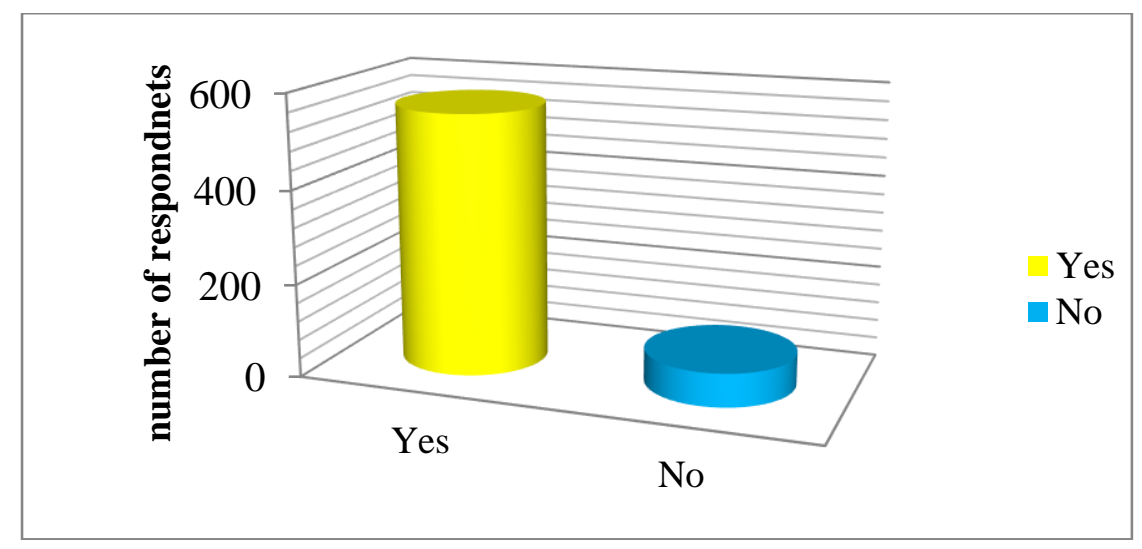

Figure 4.1 Understanding the term of New Media

Based on Figure 4.1 above, it shows $556(88.7 \%)$ respondents knew and understood the term New Media, only 71 respondents (11.3\%) did not understand the term. This happened because new media is now widely used by the society. Hence, it provides information and knowledge especially on currents issues, as well as discussion on Islamic politics. Most political topics of discussion in Malaysia are mostly about Islam. In conclusion, media is the most common place of discussion including discussion about Islamic politics.

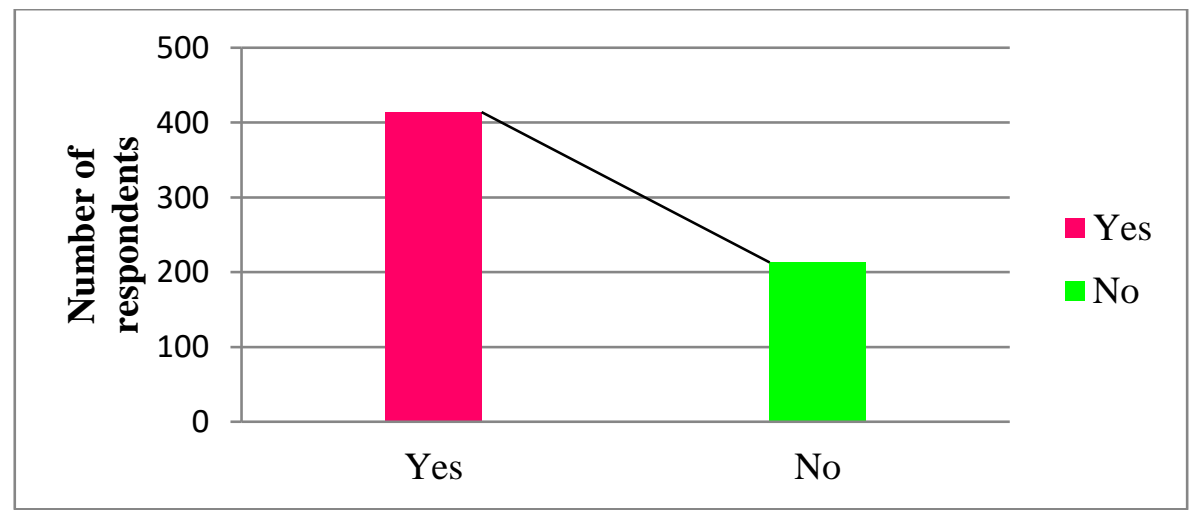

Figure 4.2 Viewers of Islamic politics websites 
The third question was also answered based on Figure 4.2 above. Based on the data, it was found that 414 respondents (66.0\%) have visited and read websites on Islamic politics and 213 respondents (34\%) never read any websites on Islamic politics. Based on the data, it clearly shows that more than 50 percent visited and read Islamic politics' websites. Hence, this proves that the new media is a platform for discussion and for users to voice out their opinions.

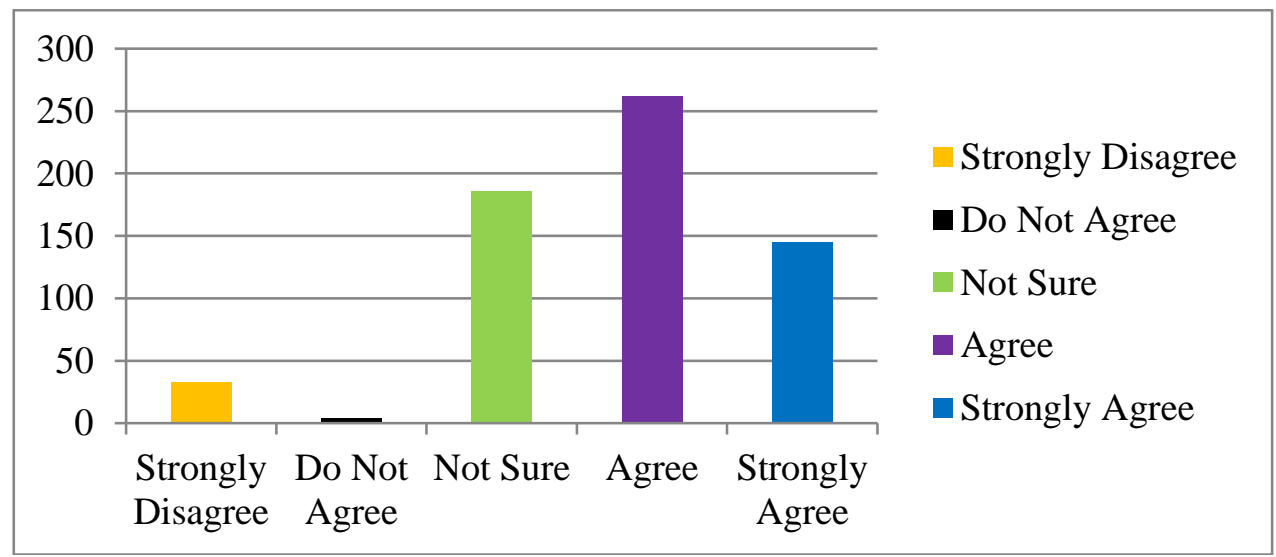

Figure 4.3 Expansion of Islamic Politics via the new media

The third question was answered and showed in Figure 4.3 above. The figure shows 262 respondents $(41.8 \%)$ and $143(22.6 \%)$ respondents respectively agreed and disagreed on the statement that discussions on the development of Islamic politics can be fully expanded through the new media. Only 4 respondents $(0.6 \%)$ and 33 respondents $(5.3 \%)$ disagreed and extremely disagreed on the statement respectively. 186 respondents $(29.7 \%)$ answered not sure on the statement. The research question on the role played by the new media in the development of Islamic politics was answered and showed in the following graphs. Question four is analysed and discussed in Figure 4.4 on the role of the new media in the development of Islamic politics until today.

Figure 4.4 How new media increased people's knowledge on Islamic Politics

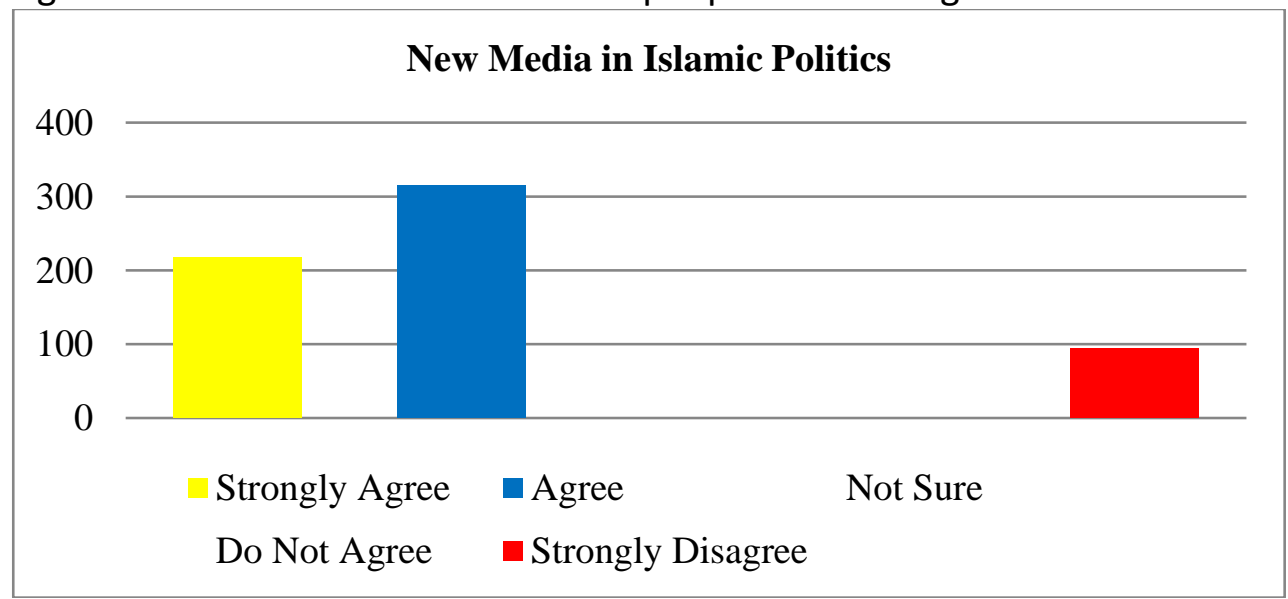

Based on Figure 4.4 above, 218 (34.8\%) respondents extremely agreed, 315 (50.2\%) agreed and 94 respondents (15\%) extremely disagreed that new media is a great help to increase people's knowledge on Islamic politics. However, none was unsure and disagreed. 
Results also show that $183(29.2 \%)$ respondents and 319 (50.9\%) respondents extremely agreed and agreed respectively on the statement that new media is the fastest way to get current information on various issues especially related to Islamic politics. Whereas, $55(8.8 \%)$ respondents disagreed and $70(11.2 \%)$ respondents extremely disagreed on that statement. The results are shown in Table 4.2 below.

Table 4.1 New Media is the fastest way to get information

\begin{tabular}{ccc}
\hline \hline Item & Number & Percentage (\%) \\
\hline New media
\end{tabular}
politics

Extremely agree

Agree

Not sure

Disagree

Extremely disagree
183

319

0

55

70
29.2

50.9

0.0

8.8

11.2

Figure 4.5 below shows the results on how respondents understand new media as a campaigning tool. Based on the research, it was found that from 627 respondents, 619 (98.7\%) respondents agreed that politicians used new media in their political campaigns. Whereas, only $8(1.3 \%)$ respondents disagreed on the statement. However, majority of the respondents agreed on the statement. From the writer's point of view, this happened because it is easier for political leaders to publish their statements via the media rather than meeting their people personally.

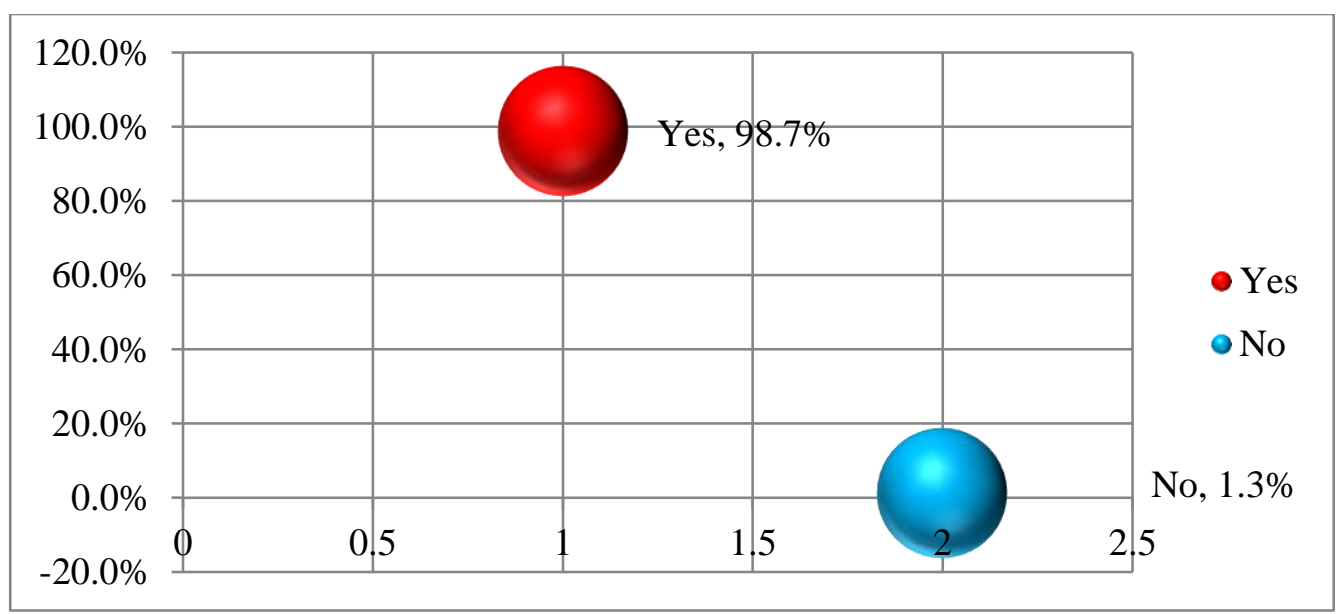

Figure 4.5 New media used by politicians in their campaigns

It is common for politicians to launch their campaign strategies before the election to influence voters. In Malaysia, politicians and their supporters are now beginning to have cyber campaign as one of their strategies. Cyber campaign is a new campaigning tactic using social applications and social internet links to deliver information and to communicate easily with the voters and supporters. 


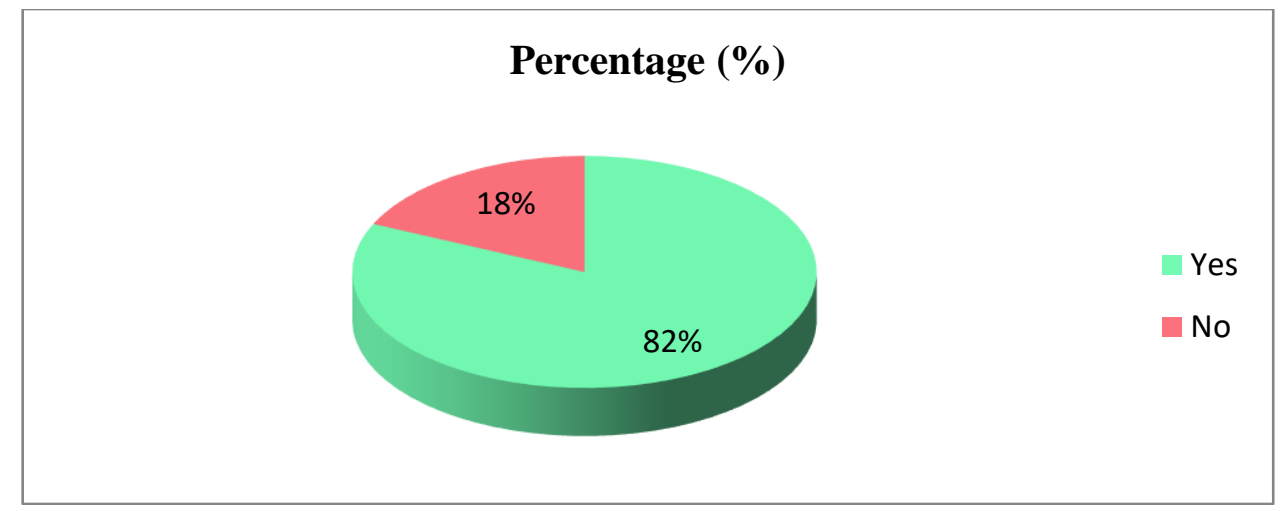

Figure 4.6: New Media is capable to change people's way of thinking

Based on Figure 4.6 above, 513 (82\%) respondents stated "Yes" and 114 (18\%) respondents disagreed on the statement that new media is capable in changing people's mind and way of thinking simply by using the new media as the channel to voice out opinions and points of views. This happened because different groups of people have different beliefs, opinions and point of views. Hence, it is easy for the common citizens to receive direct information from the new media, even without checking its credibility. This is because the influence brought by the new media is huge and even the government cannot curb the rapid flow of news and information transmitted by the media.

\section{Discussion}

Islamic politics in Malaysia is getting stronger, even political commitment and participation of UMNO and PAS, the two major parties in Malaysia are merrier than years ago. Leaders from both parties are more responsible and open in their speeches and how they work for their people (voters) and religions. This is very important and a positive sign for our future Islamic politics. In fact, the issues and ideas related to Islamic politic are published in the internet, especially via the social networks such as face book, twitter and personal blogs.

The culture of Islamic politics needs new practice and it should be practiced in a very great but humble manner. Differences in terms of political beliefs and attitudes among Islamic political parties should be based on the different in the aspects of thinking and quality of the practice. Religious behavior is a sign of different beliefs and political practice that will poison the dynamic and future Islamic politics. All parties should focus on the efforts to improve the quality of the political world especially in administering the country's policies and development programs for the benefit of the citizens. All parties should plan their politics movement and compete with other parties healthily without ignoring the Islamic culture. However, the current politicians are using ineffective ways to influence the society, for instance by publicly shame their opponents, particularly on the opponents' weaknesses in behaviors, attitudes, and belief. Politicians and supporters should shoulder their responsibility by upholding Islam as the pillar especially to fix wrongdoings for the benefits of all citizens especially the Muslim society. Hence, it can be concluded that the new media has a very significant role in the development of Islamic politics especially for politicians to establish an Islamic based-government. 


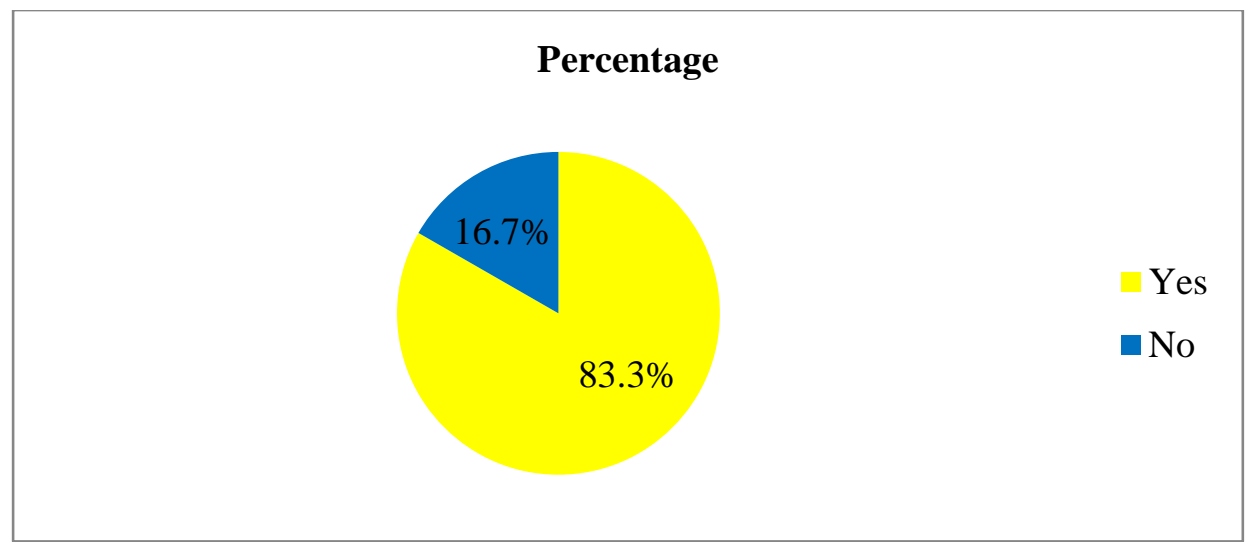

Figure 4.7 Development of Islamic politics is influenced by the new media

Figure 4.7 below shows the percentage of Islamic political development that is influenced by the new media. Based on the findings, the Figure shows that $522(83.3 \%)$ respondents have agreed with the statement that the new media influence the development of Islamic politics in Malaysia. This is because politicians use the new media as a facility to disseminate Islamic knowledge and belief, as well as to discuss issues related to Islam and politics.

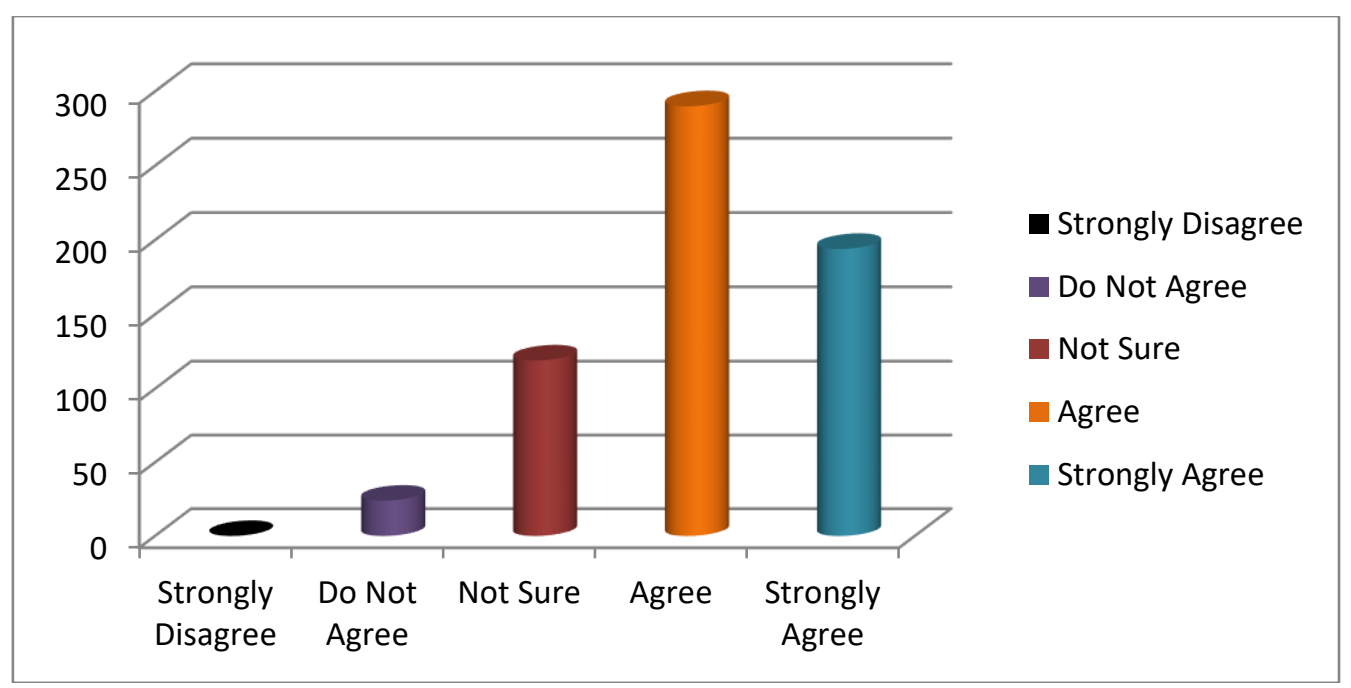

Figure 4.8 New media influences the development of Islamic Politics

Figure 4.8 above describes the statement on how new media influences the development of Islamic politics in Malaysia. The response was concentrated on the "Yes" answer. Based on the above Figure 4.8, 194 (30.9\%) respondents were extremely agreed, 290 respondents (46.3\%) agreed, 119 (19.0\%) respondents were not sure, 24 (3.8\%) respondents disagreed and none (0) extremely disagreed on the statement that new media influences the development of Islamic politics. In overall, it was found that almost 77 percent respondents agreed that new media influences the development of Islamic politics. The new media is very important in today's life, this is due to the fact that people can easily access to various information including every aspect of Islam and Islamisation. Every question and 
problem regarding Islam is easily answered and solved via the media. In addition, it enables personal interaction between an individual with the Muslim scholars.

\section{Conclusion}

This study has successfully answered the research questions on the influence of new media in the development of Islamic politics. The first research question is answered in the discussion on how the new media particularly social applications such as face book, twitter, websites and blogs are commonly used by Malaysians. All of the four popular social networks are the four main channels that have positive impacts, especially when the politicians use them as a platform for their political campaigns. Apart from that, individuals, political groups and even mere citizens to voice out their opinions and ideas on Islamic politics commonly use the new media. Malaysia is experiencing the third development phase of internet wave and globalisation. The new media is very convenient for political campaigns as it is easy, cost effective and time effective. Based on the literature review, it is found that the new media is very significant and important in everybody's life, for the commoners, the professionals and of course the politicians. The new media enables people to manage their every day's activities faster. Based on the literature review, it was found that most scholars and academicians agreed that political campaign is very important for a country that practices a democratic system. Candidates need to gain supports from the society, hence it is not a surprise when most politicians are utilising the new media as one of their campaign's venues.

Social media such as face book is really part of the youths' lifestyle. They are always connecting and updating their social accounts' status or familiarise themselves with various issues. There are always current issues related to Islamic politics being discussed online. Hence, the new media provides a wide chance and space for Islamic movement to promote Islamic knowledge. Teenagers are easily influenced by foreign cultures even those which are irrelevant with the Muslim's way of life. Hence, it is important for Muslim leaders to curb these issues by providing more information and knowledge about Islam and Muslims' lifestyle. Public discussions via the internet help Muslims to discuss and solve their problems. Cyber space is an alternative media but famously used by people to expand their influence and increase people participation.

The second research question is to know the role of media in influencing people's attitudes towards Islamic politics. Based on the writing and various discussions, it is very clear that the new media has significant impact on the development of Islamic politics. For example, there are several websites created by various Islamic institutes such as PEMBELA, ISMI, and PEKIDA, which discuss the concepts of Islam especially regarding their activities, mission, and visions. In addition, political leaders often use the new media to talk about good deeds and anything related to Muslim Malays. Based on the literature review, conclusion can be made on the concepts used by the media industry to help the government especially in providing easy access of information for the people. Transformation is a term refers to modernization in politics as an impact of the new media. Political administration is definitely involves everything that happens in a country. This is because the new media is definitely changes the society's opinions and views towards political party. 


\section{References}

Awang, A. H. (2007). Understanding and Ideology of the Muslims. PTS Islamika Sdn Bhd.

Awang, A. H. (2009). Understanding and Ideology of the Muslims, Gombak: Penerbit PTS.

Ahmad, A. M. (2011). History of Malaysian Constitution. Kuala Lumpur. Group Buku Karangkraf.

Hussain, A. A. (1998). Reformation of public administration in Malaysia. Kuala Lumpur: Utusan Publications \& Distributors Sdn. Bhd.

Othman, A. L. (2011). Final Notes. Zafar Sdn Bhd.

Pole, A. (2010). Blogging the political: Politics and participation in a networked society. Routledge: New York.

Vejai, B. (2013) The politics of locality and temporality in the 2012 Malaysian parliamentary elections. Contemporary Southeast Asia 27, No. 1 pp 4463.

Axford, B., \& Huggins, R. (2001). New Media and Politics. Sage Publications: London.

Bimber, B. (2016). Information and American Democracy: Technology in the Evolution of American Power. New York: Cambridge University Press.

Bresnahan, R. (2006). The media and the neoliberal transition in chile democratic promise unfulfilled. Latin American Perspective, Issue 133, 30 (6), 755-757.

Cohen, L., \& Morrison. (2000). Research Methods in Education. London: Routledge Falmer.

Wiersma, (2000). Research Methods in Education. London: Routledge Falmer.

Smith, D. E. (pnyt.). (1974). Religion and Modernization. New Haven. Yale University Press.

Syam, F. (2007). Western political thinking, History, Philosophy, Ideology and the impact on the third world countries. Jakarta: PT Bumi Aksara.

Fisher, B. A. (1986). Communication theories. Bandung: Remadja Karya.

Iszahanid, H. (2012). The Malacca's Empire: The Greatest Malays' Tradition. BH: Perbadanan Muzium Negeri Melaka.

Howard, P. N. (2006). New media campaigns and the managed citizen. New York: Cambridge University Press.

Internet World Stats Usage and Population Statistics. (2012). http://www.internetworld stats.com/stats3.htm. [20 Januari 2013].

Hamil, J. H. (2005). UMNO in the Malays' Politics and Business. Bangi: Penerbit Universiti Kebangsaan Malaysia.

Jowett, G. S., \& O’Donnell, V. (2006). Propaganda and persuasion seventh edition. United State: Sage

Abdullah, K. (2003). The Politics of Islam In the Contemporary Malaysia. Bangi: Penerbit Universiti Kebangsaan Malaysia.

Dewan Bahasa dan Pustaka. (2005). Kamus Dewan Bahasa Edisi Keempat. Kuala Lumpur: Penerbit Dewan Bahasa dan Pustaka.

Dewan Bahasa dan Pustaka. (1991). Kamus Dewan Edisi Baru. Kuala lumpur: Dewan Bahasa dan Pustaka.

Kaur, K., \& Ramanathan, S. (2016). Wither media laws? Experiences of Malaysia and Singapore. Journal of International Communication. 14(1): 7-21.

Ahmad, K. (1979). Islam and the West. Lahore: Islamic Publication Ltd.

King, D. (1997). The Commissar Vanishes: The Falsification of Photographs and Art in Stalin's Russia. The Art Bulletin. 80(4), 755-757.

Kulikova, S. V., \& Perlmutter, D. D. (2017). Blogging down the dictator? The Kyrgyz Revolution and Samizdat websites. International Communication Gazette, 69(1):29-50.

Lasswell, H. D. (1938). Propaganda technique in the world war. New York: Peter Smith. 
Fraser, L. (1945). Germany between two wars. A study of propaganda and war guilt. New York: Oxford University Press.

Thaib, L. (1998). Politics from the Islamic perspectives. Kajang: Synergymate Sdn Bhd.

Maududi. (1969). Islamic law and constitution. Lahore: Islamic Publication Ltd.

Brahim, M. (2002). Public policies in Malaysia: Respond to the latest issues. Universiti Utara Malaysia.

Marshall, M. (2011). Understanding media: the extensions of man. Giddings, set hand Martin Lister. The new media and techno cultures reader, New York: Routledge, hlm 79-91.

McQuail, D. (1987). Communication theory: An Introduction. London: Sage.

Musa, S., \& Nor, M. (2008) Analisa pasca pilihan raya umum Malaysia 12: Negeri-negeri selatan semenanjung benteng terakhir Barisan Nasional. Cabaran dan Harapan. Kertas kerja Seminar Pasca PRU12. FSPPP UiTM Shah Alam. 15 April 2008.

Pharr, Ellis, S. \& Krauss (eds.). (1996). Media and politics in Japan. Honolulu: University of Hawaii Press.

Pratkanis, A., \& Aronson, E. (1992). Age of propaganda: The everyday use and abuse of persuasion. New York: W.H. Freeman and Company.

Wah, L. K., \& Saravanamuttu, J. (2016). 'New politics in Malaysia'. Selangor. Prentice Hall: Pearson Malaysia Sdn. Bhd.

Sumarsono, S. (2001). Citizenship education. Jakarta. Gramedia Pustaka Utama.

Abdullah, S. (2017). Mamatangkan demokrasi Malaysia. Skudai. Universiti Teknologi Malaysia.

Rahim, A. S. (2008). Media and the younger generation. Putrajaya: Institut Penyelidikan Pembangunan Belia Malaysia.

Severin, W. J., \& Tankard, J. W. (2005). Teori komunikasi: Sejarah, metode, dan terapan di dalam media massa edisi kelima. Jakarta: Kencana.

Bakers, S. (2012). Facebook user statistics. http://www.socialbakers.com. [25 Disember 2012].

Sunarjo, D. S., \& Sunarjo. (1982). Mengenal Propaganda. Yogyakarta: Liberty.

Tunku Iskandar, T. (1985). Kamus Dwibahasa. Kuala Lumpur: Dewan Bahasa dan Pustaka.

Suharto, U. (2007). Islamic Liberal Thinking. Shah Alam: Dewan Pustaka Fajar.

Zaller, J. (1999). A Theory of media politics: How the interests of politicians, journalists and citizens shape the news. Chicago: University of Chicago Press

Sulong, Z. (2012). The People's Mind.

http://www.mindarakyat.com/v3/index.php/kategori/163-penulis. html. [22 Mac 2013]. 